\title{
Association Between Nutritional Status and Age at Menarche
}

\author{
Asrika Sari Harahap, Heru Santosa, Albiner Siagian
}

Masters Program in Public Health, Universitas Sumatera Utara

\begin{abstract}
Background: Menarche age is often considered for various reasons. It is one of the major indices of the female fertility which includes the period up to the menopause. More critically, menarche marks the onset of ovarian activity associated with reproduction, and affects breast cancer risk. Some earlier studies reported that subjects who had menarche before 13 years of age were at a significantly higher risk of cancer cervix. Nutrition has an important bearing on age at menarche. Menarche is attained earlier by well nourished adolescents. This study aimed to assess the relationship between menarche age and body mass index.

Subjects and Method: This was a cross sectional study conducted at Ki Hajar Dewantara Foundation Junior High School, Kota Pinang, Labuhanbatu Selatan, North Sumatera, in December 2017. A sample of 58 school girls attending the Junior High School were selected for this study. The dependent variable was menarche age. The independent variable was body mass index (BMI). Body weight was measured by a scale. Body height was measured by micro toise. Other variables were measured by questionnaire. The data were analyzed by a simple logistic regression.
\end{abstract}

Results: $\mathrm{BMI} \geq 25$ was associated with an earlier menarche age $(\mathrm{OR}=0.71 ; 95 \% \mathrm{CI}=0.20$ to 0.85 ; $\mathrm{p}=0.046)$.

Conclusion: $\mathrm{BMI} \geq 25$ is associated with an earlier menarche age.

Keywords: menarche age, body mass index, adolescents

\section{Correspondence:}

Asrika Sari. Masters Program in Public Health, Universitas Sumatera Utara, Jl. Universitas No.21, Medan 20115, North Sumatera, Indonesia, Email: asrikasariharahap1993@gmail.com. Mobile: +6282274134348 .

\section{BACKGROUND}

Adolescence or menarche age is a stage between childhood and adulthood. According to WHO, called adolescence is a population of the age range of 10-19 years (Infodatin, 2012). Adult transitions vary, but generally it is defined as the time when individuals begin to act regardless of their parents. Growth and development in adolescence is very rapid, both physical and psychological. As for one of the developments that occur in adolescents, especially young women, is marked by the arrival of menarche. But even so, they often fail in their growth and development. Many factors influence these failures such as genetic, nutritional status, social, economic and others (Proverawati, 2009).

According to the 2010 Basic Health Research (Riskesdas) in Indonesia the average age of menarche for young women is 13 years with an earlier occurrence at ages less than 9 years and slower to 20 years. At present, there is a tendency for children to get menarche at a younger age. The change in age of menarche in adolescents is one of them caused by an improvement in nutrition in the family.

The results of Aishah (2011) study concluded that female students who had a higher nutritional status (BMI) tended to get menarche faster. In line with Munda's research (2012) that female students with 
overweight nutritional status experience menarche faster than female students with normal and underweight nutrition status.

The age of menarche that is too fast in adolescents can cause teenage unpreparedness and problems due to maturation of the reproductive organs which will provide sexual drive and can cause problems such as unwanted pregnancies (Fadhilla in Putri, 2009). In addition, too fast menarche is also a risk factor for breast cancer, ovarian cancer, the risk of cardiovascular disease and also a greater use of it (Kaparanou, 2010).

\section{SUBJECTS AND METHOD \\ 1. Study Design \\ This was a cross sectional study conducted at Ki Hajar Dewantara Kotapinang College Foundation, Medan, Indonesia.}

\section{Population and Samples}

The population in this study were all young women from the $\mathrm{Ki}$ Hajar Dewantara College Foundation Kotapinang starting from class VII to XII amounting to 784 students. While the sample in this study were students who had experienced menstruation for the first time, namely amounting to 58 students selected through simple random sampling technique.

\section{Study Intruments}

The instruments used were questionnaires, manual and microtoise scales. The dependent variable in this study was the age of menarche in young women aged 13-18 years at Ki Hajar Dewantara College Foundation Kotapinang. The independent variable is nutritional status (BMI).

Research ethics was obtained from the foundation or the school, then giving an explanation to the respondent, asking the respondent's willingness and filling out informed consent, giving the questionnaire and measuring the height and weight.

\section{Data analysis}

The data were analyzed by a multiple logistic regression.

\section{RESULTS}

The majority of respondents in this study were at the age of 15-16 years old, who were 32 female students (55.2\%). On the characteristics of the respondents based on the class, the most female students in class $\mathrm{X}$ SMK were 22 students (37.9\%). The majority of nutritional status (BMI) in the normal category was 46 female students (79.3\%). Whereas in the age variable menarche was dominated by the normal age of menarche which was 30 female students (51.7\%). Characteristics of respondents can be seen in Table 1.

\section{Table 1. Sample Characteristics}

\begin{tabular}{lcc}
\multicolumn{1}{c}{ Characteristics } & Total & \% \\
\hline Age & & \\
$13-14$ & 5 & 8.6 \\
$15-16$ & 32 & 55.2 \\
$17-18$ & 21 & 36.2 \\
Class & & \\
VII & 3 & 5.2 \\
VIII & 2 & 3.4 \\
IX & 2 & 3.4 \\
X & 22 & 37.9 \\
XI & 15 & 25.9 \\
XII KK & 14 & 24.1 \\
Nutritional & & \\
Status (BMI) & & \\
Normal & 46 & 79.3 \\
Abnormal & 12 & 20.7 \\
Age of Menarche & & \\
Normal & 30 & 51.7 \\
Abnormal & 28 & 48.3 \\
\hline
\end{tabular}

The relationship between nutritional status and age of menarche in adolescent girls can be seen in Table 2. The data showed a significant relationship between nutritional status (BMI) and the age of menarche of female adolescents $(\mathrm{OR}=0.71$; $95 \% \mathrm{CI}=0.20$ to $0.85 ; \mathrm{p}=0.046$ ) 
Table 2. The Relationship between BMI and the Age of Menarche

\begin{tabular}{lccccc}
\hline \multicolumn{1}{c}{ Nutritional } & \multicolumn{2}{c}{ The Age of Menarche } & \multirow{2}{*}{ OR } & p \\
\cline { 2 - 3 } \multicolumn{1}{c}{ Status } & Abnormal & Normal & & 0.71 & 0.046 \\
\hline Normal & 23 & 23 & & \\
\hline
\end{tabular}

\section{DISCUSSIONS}

The age of menarche in this study was influenced by nutritional status, it can be said that with nutritional status (BMI) $\geq 25$ or fat category would accelerate the age of menarche while if the BMI of female adolescents was $\leq 17$ then the age of menarche was slower. Sarwono (2012) stated that there were several factors that influence variations in age of menarche and one of them was the presence of nutritional factors. Even a study showed that the average age of menarche in urban area was faster than in villages because the condition of nutrition in urban area was better than in villages.

This study was in line with Lasandang (2016) which stated that there was a relationship between nutritional status (BMI) and age of menarche.$$
\text { REFERENCES }
$$

Aishah (2011). Hubungan Status Gizi dengan Usia Menarche pada Remaja Putri. Skripsi

Infodatin (2012). Situasi Kesehatan Reproduksi Remaja. Diakses dari http://www.google.com/url?sa=t\&source $=-$ web\&rct=j\&url=http://depkes.go.id/d ownload.php\%3Ffile\%3Ddownload/p usdatin/infodatin/infodatin\%250repr oduksi\%25oremajaed.pdf\&ved=2ahU
}

KEwir_a3lpp7aAhWLuY8KHRv1A7o QFjAEegQIBhAB\&usg=AovVaw3nA5 XtMOi4j-zJO-uX7Wn6.

Karapanou O, Papadimitriou A (2010). Determinants of menarche. Reproductive Biology and Endocrinology, 8, 115. Diunduh dari http://www.rbej.com/content/8/1/115

Lasandang N, Kundre R, Bataha Y (2016). Hubungan Status Gizi dengan Usia Menarche pada Remaja Putri di SMP Negeri 6 Tidore Kepulauan. Skripsi

Munda et al. (2012). Hubungan Status Gizi dengan Usia Menarche pada Remaja Putri. Skripsi

Proverawati A (2009). Menarche (Menstruasi Pertama Penuh Makna), Yogyakarta : Nuha Medika.

Putri AK (2009). Hubungan antara status gizi, status menarche ibu, media massa, aktivitas olahraga dengan status menarche sisiwi di SMP Al-Azhar Ramawangun Jakarta Timur. Skripsi. FKM UI, Jakarta.

Riskesdas (2010). Perkembangan status kesehatan masyarakat Indonesia, Jakarta: Badan Penelitian dan Pengembangan Kesehatan Kementrian Kesehatan Republik Indonesia. Diakses dari http://www.riskesdas.litbang.depkes.go.id 